Jobbitt, Steven. "Seegel, Steven. 2018. Map Men: Transnational Lives and Deaths of Geographers in the Making of Modern East Central Europe. Chicago and London: Chicago University Press. 346 pp., illus." Hungarian Cultural Studies. e-Journal of the American Hungarian Educators Association, Volume 12 (2019) DOI:

10.5195/ahea.2019.370

\title{
Seegel, Steven. 2018. Map Men: Transnational Lives and Deaths of Geographers in the Making of Modern East Central Europe. Chicago and London: Chicago University Press. 346 pp., illus.
}

\author{
Reviewed by Steven Jobbitt ${ }^{1}$, Lakehead University
}

A combination of biography and transnational history, Steven Seegel's Map Men: Transnational Lives and Deaths of Geographers in the Making of Modern East Central Europe offers new and important insight into the inner lives, friendships, and complex emotional landscapes that informed the work of five geographers who were instrumental to the making of modern East Central Europe. Taking the reader back to a time when geography and its practitioners were central — even essential - to both global diplomacy and nation-building politics, Seegel illustrates the ways in which his geographers, the so-called "homo geographicus of the 1870 s to the 1950 s" (227), attempted to maintain transnational relationships with one another under the guise of objective science, while simultaneously dedicating themselves and their research to "the service of the state" (128). As Seegel argues, this was a delicate balancing act that none of the men in his study could manage successfully or maintain indefinitely. Identifying World War I as a clear turning point, Seegel shows us just how quickly the cherished scientific objectivity of the late nineteenth century gave way to the subjective politics of national and imperial interests, and how "map wars" themselves both reflected and inflamed conflicts between states.

At the center of Seegel's story is the German geographer Albrecht Penck (1858-1945) and four other men that Seegel introduces as "Professor Penck's pupils": the Polish geographer Eugeniusz Romer (1871-1954), the Ukrainian geographer Stepan Rudnyts'kyi (1877-1937), the Canadian-born American geographer Isaiah Bowman (1878-1950), and the Hungarian geographer and politician Count Pál Teleki (1879-1941). Pointing to a shared set of academic principles and professional ideals and practices that were cultivated "within the civilizing confraternity of a scientific community," Seegel identifies all five men as "transnational Germans" whose love affair with maps and geographical science was the basis of a bond that, though strained by international events and interpersonal disagreements, was rarely severed entirely (5). The personal and professional relationships between these men - relationships that were forged on the basis of shared educational experiences and interpersonal contact in the field - are at the heart of Seegel's study. By examining their on-again, off-again friendships (or "bromances"), Seegel argues that we gain new insight into their work and into the maps that were the crowning achievements of lives dedicated both to geographical science and civic duty.

${ }^{1}$ sjobbitt@lakeheadu.ca

$($ (c) $)$ EY

ULIS D-Serke 
Jobbitt, Steven. "Seegel, Steven. 2018. Map Men: Transnational Lives and Deaths of Geographers in the Making of Modern East Central Europe. Chicago and London: Chicago University Press. 346 pp., illus." Hungarian Cultural Studies. e-Journal of the American Hungarian Educators Association, Volume 12 (2019) DOI:

Scrutinizing their interconnected biographies, and in particular their voluminous correspondence with one another - correspondence that is at the heart of what he calls "epistolary geography"Seegel contends that these geographers "left behind...the psychological clues that detail the character formation of fragile aspirational professionals who believed in science, yet dreamt up and participated in illiberal projects" (227).

Though Seegel could perhaps have done more to explain why an arguably recent term like "illiberalism" can and should be applied to the interwar period, his point is well taken, and instructive. Arguing that the harnessing of geography to nationalist aspirations during World War I and to increasingly radical political goals during the interwar period should not come as a surprise, Seegel traces the illiberal turn of his geographers back to the nineteenth century, which, he maintains, "should not escape culpability" (148). In making such a claim, Seegel is not shifting the blame or focus away from the twentieth century, and especially the post-World War I period, nor is he suggesting that we draw a straight line from nineteenth-century geographical science to the intolerant and ultimately genocidal geopolitics of World War II, but only that the deeper, longer history is important to take into consideration. Fin-de-siècle science gave rise to a variety of outcomes and possible paths forward. By scrutinizing the intertwined transnational biographies of five leading geographical scholars from the period, we catch an important glimpse into a particular trajectory that led to tragic ends and had horrific consequences.

Seegel's exposition of the nineteenth-century link between geography and illiberal politics is compelling, as is his assessment that maps themselves are problematic, and that as projections of power and (geo)political desire they need to be read carefully and critically. Such observations are hardly new, but Seegel's masterful telling of how the key maps of his geographers were produced (and ripped apart by their critics) compels us to look beyond the mere political and ideological dimensions of the cartography of this era, and to take seriously the emotional and psychological dispositions of the men who made and criticized these maps. Forged at the intersection of race, class, and masculinity, and informed by a set of hopes, fears, and frustrations that were themselves amplified by the transnational fraternity they belonged to, the maps produced by these map men cannot be viewed merely as "rational plans" for "an abstractly ordered modernity." Rather, these maps "expressed concealed moods and illusory bonds" (164). When read against the backdrop of unstable relationships and the inner lives (and deaths) of the five geographers, Seegel concludes that we can see just how fleeting and unstable their "rationalized" tracings of a supposed reality really were. Just as "all moods are fleeting, and all bonds dissolve," maps, he argues, at best reflect only "an illusion of permanence" (164).

One of the key strengths of Seegel's book is that it is a collective biography of five men, and the breadth he achieves with his narrative is both admirable and impressive. However, by casting such a wide net, it is perhaps inevitable that some of the finer details of the lives of the men he has studied might be missed, or glossed over. Readers familiar with Hungarian history, for example, might rightly recoil at the notion of Teleki as a "transnational German," while experts in the field are likely to quibble with Seegel's characterization of Teleki as a "playboy count" whose "half-baked ideas" became the basis of interwar Hungarian geography (84). Such criticisms are not without merit. Though Teleki, like all other geographers in Central and East Central Europe at the time, was no doubt influenced by developments in German science, he can hardly be seen as one of Penck's pupils, at least not directly. As Seegel himself notes, much of what Teleki knew about Penck and the German geographical tradition was conveyed to him by 
Jobbitt, Steven. "Seegel, Steven. 2018. Map Men: Transnational Lives and Deaths of Geographers in the Making of Modern East Central Europe. Chicago and London: Chicago University Press. 346 pp., illus." Hungarian Cultural Studies. e-Journal of the American Hungarian Educators Association, Volume 12 (2019) DOI:

his own scientific "father," the Zürich-trained Hungarian geographer and geologist Lajos Lóczy (1849-1920). But in the decade before World War I, Teleki had grown critical of the German tradition, and in criticizing thinkers like the political geographer Friedrich Ratzel (and by extension also Penck) as being too mechanistic, Teleki turned consciously toward French géographie humaine, and in particular the works of the leading French geographer Vidal de la Blache (1845-1918). Far from being "half-baked," the synthetic approach to geography that Teleki introduced to Hungarian geography was a critical, if obviously Hungarian-centric, rereading of the existing European geographical traditions of the time. This, of course, does not render Teleki's geography more legitimate or objective. It simply points to the need for a more careful consideration of the scientific work he was engaged in, and the schools of thought for which he laid the groundwork in post-World War I Hungary.

Although some of Seegel's factual claims regarding Teleki may be open to question, the general thrust of his argument is nevertheless sound, and what he reveals with respect to one of Hungary's most well-known geographers and the transnational network of map men to which he belonged is a welcome addition to the literature. Teleki was a leading member of a generation of conservative-nationalist scholars who were largely forgotten during the socialist era, but whose lives and work have been rediscovered by scholars, politicians, and populist dilettantes alike since 1989, and especially since the early 2000s. Even though critical examinations of Teleki's legacy have been undertaken by some Hungarian scholars, we are still a long way from coming to terms with Teleki as an important interwar scholar and politician. Teleki remains a controversial figure, and for good reason. Whereas some would see Teleki rehabilitated completely and unapologetically, Seegel encourages us to look more closely at the darker side of Teleki's story, and to put this in a broader regional and even global context. When examined alongside the transnational lives and deaths of the other four men in Seegel's study, it becomes patently clear that Teleki was not the exception, but rather the rule. Readers who have become invested in the rehabilitation of these map men individually or collectively will no doubt take issue with Seegel's characterization of them as "unlikeable heroic explorers, intolerant antiheroic careerists, and privileged transcultural racists" (232), but given what we know about the politics of the era more broadly, and the role these men played in supporting "illiberal" antisemitic regimes both directly and indirectly, it is high time we take a harder look at the political dimensions and implications of their work. A close reading of Map Men is certainly a good place to start.

From the point of view of history and geography, Seegel's focus on the transnational dimensions of Teleki's life and work is perhaps his most valuable contribution to Hungarian studies. For a variety of reasons - with language perhaps chief among them-Hungary is often left out of comparative work on the region, and in this light Seegel's commitment to learn Hungarian and to consult Hungarian archives and Hungarian-language sources is commendable as well as very valuable. It is all-too-rare for a non-Hungarian specialist to draw the Hungarian story into a broader, transnational analysis, and the existing literature is all the poorer for it. Regardless of Seegel's possible oversights with regard to Teleki's intellectual development and scholarship, his book integrates Hungary's infamous geographer-politician into a critical discussion of the intersection of geography, integral nationalism, and the rise of the right in the first half of the twentieth century. Combined with his focus on the personal and undeniably emotional aspects of geographical knowledge production during this period, Seegel's study 
Jobbitt, Steven. "Seegel, Steven. 2018. Map Men: Transnational Lives and Deaths of Geographers in the Making of Modern East Central Europe. Chicago and London: Chicago University Press. 346 pp., illus." Hungarian Cultural Studies. e-Journal of the American Hungarian Educators Association, Volume 12 (2019) DOI:

should leave no doubt in the reader's mind about the importance of looking deeply into the lives of nationalist intellectuals, and about the need to construct an analytical framework that includes not only the dynamics of race, gender, and class, but also personal ambition and failure, and the promise and frustration of interpersonal relationships.

If anything, having reached the end of Seegel's narrative, I wished there had been a more sustained theoretical discussion in it of the processes through which the emotional and psychological dispositions of geographers are translated into maps, and the ways in which geographical knowledge production more generally intersects with masculine performances of the geographer-as-expert. This is not, of course, a critique of Seegel's study, but rather the expression of a desire to see more work done in this vein. Meticulously researched, Map Men is a real achievement as a work of transnational history and collective biography, and it will undoubtedly make important contributions to a number of sub-fields in the history and geography of modern East Central Europe. 